\title{
Influence Competence And Placement of Employee On Employee Performance At PT. Xylo Indah Pratama in Musi Rawas Regency of Muara Beliti
}

\author{
Ronal Aprianto, Fitria, Suyadi, Suwarno, Yulpa Rabeta \\ ${ }^{1}$ Lecturer in Bina Insan University Lubuklinggau
}

\section{ARTICLE INFO}

AIJ use only:

Received date : 06 June 2020

Revised date : 23 June 2020

Accepted date : 15 July 2020

Keywords:

Competence

Employee placement

Employee performance

\section{A B S T R A C T}

This research was conducted to determine the effect of employee competency and placement on employee performance at PT. Xylo Indah Pratama Muara Beliti Musi Rawas Regency. The results of this study indicate that there is a significant effect between Competency and Employee Placement on Employee Performance.

\section{INTRODUCTION*}

Human Resource Management (HR) is important in achieving goals. Generally company leaders expect good performance from each employee in carrying out the tasks given by the company. The company realizes that HR is the basic capital in the process of building a company and even nationally, therefore the quality of HR must always be developed and directed in order to achieve the goals have been set by the company.

The success and excellence of the company can be achieved if employees can carry out their roles well in carrying out the company's strategy. Employees are needed by the company that is competent and capable employees in their fields. Adequate employee competency and in accordance with organizational demands encourage better achievement of organizational performance and goals.

Employee performance is often not optimal due to several reasons including the lack of support for quality human resources. Employees often feel that their duties and responsibilities are not commensurate with their abilities. Owned

\footnotetext{
Corresponding author.

E-mail address: yantimambua01@gmail.com

Article with open access under license
}

competencies based on education is taken, work, interests, knowledge and skills possessed by employees as well as the complexity of the work for which be are responsible them often not accounted by leaders when will place employees in certain positions and tasks.

According to (Busro, 2018) competence is everything that is owned by someone in the form of knowledge skills and other internal factors of individuals to be able to do something based on their knowledge and skills

Employee placement can affect employee performance in completing work who have been provided by the company. The placement of employees based on their competencies can help improve employee performance optimally.

Companies can place employees based on competencies effectively. Before organizing these activities, a good plan should be carried out with due regard to all factors relating to employee competence and placement so that what is done can work well. Of course this must be adjusted to the intent of the ability of the employee's performance in completing work which can later help in the achievement of company goals.

According to (Silalahi \& Mifka, 2015) placement is a task or reassignment of an employee to a new or different job. This includes the initial assignment of new employees and the promotion, transfer and employee demotion 
Employee placement in accordance with academic competencies are owned by employees realy helps employees in completing work is provided by the company. This means that the company must really put the employee in the position according to the competency of the employee.

In Musi Rawas, many companies are engaged in the forestry sector. One of them is the company PT. Xylo Indah Pratama, which developed rapidly in the last few years. The number of competitors requires this company to improve the quality of employee performance so that the company's goals can run optimally.

PT. Xylo Indah Pratama (XIP) is an industrial company that produces pencil slats. This company is located at Jalan Raya Palembang KM. 25 Muara Beliti. As for the raw materials for pencil slats are produced that is pulai wood, jabon wood, and pumpkin. The company has two working hours, morning work hours and afternoon work hours.

This company is very helpful to the surrounding community in their efforts to overcome unemployment. Recruitment of employees who are always open to the public be interest of community to join in working at this company.

\section{THEORY/CALCULATION (if any) Performance}

According to (Kasmir, 2018) performance is the result of work and work behavior that has been achieved in completing tasks and responsibilities given in a certain period.

According to (Silalahi \& Mifka, 2015) the basic principles of performance are:

a. Honesty and Service

b. Responsibility and Consensus

c. Cooperation and Two-Way Communication

d. Sharing Hope, Managing Behavior, Playing and Feeling Pity

According to (Wibowo, 2016) the performance methods are:

a. Feedback

Namely human resources, capital, materials, equipment, technology, methods and mechanisms of work.

b. The benefits

The impact of result of work can be positive for the company.

c. Process

Conducted transparently, especially for people who are affected by decisions that arise and people get the opportunity through the basis of making a decision.

d. Output

Is a direct result of the company's performance, both in the form of goods and services.

According to (Fahmi, 2012) the stages of performance are as follows:

a. Work is achieved individually or institutionally

b. People or institutions are given authority and responsibility

c. Work must be done legally

d. Work is not contrary to morals or ethics

According to (Soetrisno, 2016) factors that influence performance are:
a. Effort
b. Abilities
c. Role or Task Perception

\section{Competence}

According (Sedarmayanti, 2017) competence is a prowess, skill, ability that refers to the attributes or characteristics of someone who makes it successful in work.

According to (Sudarmanto, 2014) the basic principles of competence are:
a. Impulse (Motive)
b. characteristic, character, traits and innate character
c. Social role
d. Self-image
e. Skill

According to (Wibowo, 2016), the competency stages can be seen from their behavior, including:
a. Relationship
b. Talk achievement
c. Personal attribute
d. Managerial and Leadership

According to (Sudarmanto, 2014) the factors that influence competence are:
a. Trust and value
b. Expertise or skills and experience
c. Personal characteristics and motivation
d. Emotional issues and intellectual capacity 


\section{Employee Placement}

According to (Yuniarsih, 2016) employee placement is placing prospective employees who are accepted on positions or jobs that need it and at the same time delegate authority to that person.

According to (Badriyah, 2017) as for the basic principles of employee placement are:

a. Encourage employees to look for promotions.

b. Encourage employees in terms of job transfer which helps the HR department to fill positions from within and fulfill employees' personal goals.

According to (Sulistiyani, 2018) the method for placing employees is:

a. Seek budget approval to hold or fill positions.

b. Determine HR needs.

c. Develop valid placement criteria.

d. Procurement (Recruitment).

e. Carry out a test or should screen applicants.

f. Prepare a list of qualified applicants and employees.

g. Hold the selection of the most qualified employees.

According to (Badriyah, 2017) the stages of employee placement are:

a. There is an authority to place personnel who come from the list of personnel developed through workforce analysis.

b. Must have a standard that is used to compare job candidates.

c. In the event of a misplacement, a readjustment program for the relevant employee is required according to the expertise he has.

d. Putting back in a more suitable position.

e. Reassign with tasks that match talent and ability

f. Must have job applicants who will be selected for placement.

According to (Suwatno \& Priansa, 2011) the factors that influence employee placement are:
a. Promotion
b. Transfers and Demotion
c. Job information program

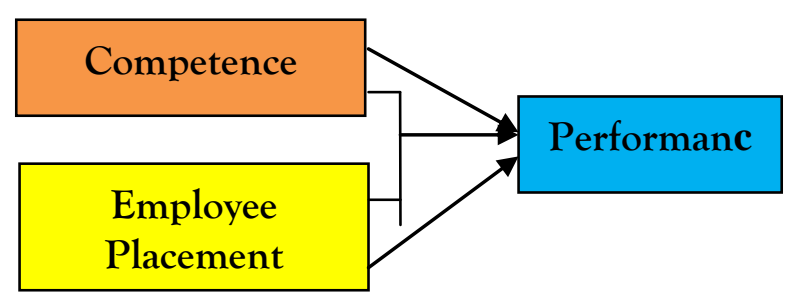

\section{METHOD \\ Research design}

The research design in this study is as follows:

1) Conduct a survey or visit research sites with the aim to find out the location and approach.

2) After that the researcher formulates the research problem and determines the survey objectives.

3) The researcher determines a title in accordance with the problem to be discussed, namely the Effect of Competence and Employee Placement on Performance at PT. Xylo Indah Pratama Muara Beliti Musi Rawas Regency.

4) Determine concepts and explore literature on employee competence and placement and performance.

5) Taking samples and making observations and making questionnaires.

6) Fieldwork (interviews and documentation) and data processing.

7) Data analysis is an activity that requires researcher's accuracy in determining the technique of analyzing data to fit the type of data.

8) Reporting is the result and summary of research and recommendations given by researchers.

\section{Population and Sample}

The population in this study were permanent employees of PT. Xylo Indah Pratama with 124 employees.

By using the Issac and Michael formula, the sample size is 44 respondents from PT. Xylo Indah Pratama Muara Beliti Musi Rawas Regency. By using simple random sampling techniques or done randomly. 


\section{Data collection technique}

Data collection by distributing questior Journal of Social Science | Jsss.co.id 85 employees or r $\mathbf{1}$. Xyı Inaan rratama viuara belıı Musi Rawas Regency. The questionnaire was filled and answered so then be returned to the researcher.

\section{RESULTS AND DISCUSSION DISCUSSION \\ Simple Linear Regression Analysis, Correlation Coefficient Analysis and T-Test Analysis of Competency variables (X1) on Employee Performance (Y)}

From the t-test calculation it is known that the t-test results show that the Competency variable (X1) has a t-value of 7.834 which is greater than the $\mathrm{t}$-table value at the real level of 2.015 or it can be said that the Competency variable (X1) has a significant effect on the Employee Performance variable (Y).

The first hypothesis which states that there is a partially significant influence between Competency (X1) on Employee Performance (Y). Based on the results of data processing, the calculated value for Competence (X1) is 7.834 while the table is 2.015 . From these data it is found that tcount is greater than ttable (t-count> t-table). Then it can be concluded that partially Competency variable (X1) has a significant positive effect on Employee Performance variable (Y).

\section{Simple Linear Regression Analysis, Correlation Coefficient Analysis and T-Test Analysis of Employee Placement Variables (X2) on Employee Performance (Y)}

From the t-test calculation it is known that the result of t-count shows that the Employee Placement variable (X2) has a t-value of 6.535 greater than the t-table value at the real level of 2.015 or it can be said that the Employee Placement variable (X2) has a significant effect on the Employee Performance variable (Y).

The second hypothesis which states that there is a partially significant influence between Employee Placement (X2) on Employee Performance $(\mathrm{Y})$. Based on the results of data processing, the calculated value for Employee Placement (X2) is 6.535 while the table is 2.015 .
From these data it is found that $\mathrm{t}$-count is greater than t-table (t-count $>\mathrm{t}$-table). Then it can be concluded that partially the Employee Placement variable (X2) has a significant positive effect on the Employee Performance variable (Y).

Multiple Linear Regression Analysis, Determination Coefficient Analysis (R2), and $F$ Test Analysis of Competency Variables (X1) and Employee Placement (X2) on Employee Performance (Y)

By using a 95\% confidence level, $a=5 \%$, df1 (number of variables -1$)=2$ and df $2(\mathrm{n}-\mathrm{k}-1)$ or $(44-2-1)=41$. The calculated $F$ value is 34,020 with a significance level of 0,000 . Where if $F$ arithmetic $>\mathrm{F}$ table then $\mathrm{Ho}$ is rejected and $\mathrm{Ha}$ is accepted. Conversely, if Fcount $<\mathrm{F}$ table then Ho is accepted and $\mathrm{Ha}$ is rejected. In this study it turns out that Fcount $(34,020)>$ Ftable $(3,226)$, meaning that Ho is rejected and Ha is accepted. This shows that there is a significant influence between the variables of Competency (X1) and Employee Placement (X2) on Employee Performance (Y).

The third hypothesis which states that there is a significant influence together between Competency (X1) and Employee Placement (X2) has a positive effect on Employee Performance (Y). Based on the results of data processing, the value of F-count is 34.020 while the F-table is 3.226 . The data shows that F-count is greater than F-table (Fcount> F-table). Then it can be concluded that simultaneously Competency (X1) and Employee Placement (X2) variables have a significant positive effect on Employee Performance (Y).

\section{CONCLUSION}

Based on research from the analysis results in accordance with the research problem formulation, the researcher can conclude that:

1) Competency Variable (X1) has a significant effect on Employee Performance (Y).

2) Employee Placement Variable (X2) has a significant effect on Employee Performance (Y).

3) Competency Variables (X1) and Employee Placement (X2) significantly influence Employee Performance (Y). 


\section{REFERENCES}

1. Badriyah, Mila. (2017). Manajemen Sumber Daya Journal of Social Science | Jsss.co.id 86

2. Busro, Muhamamad. (2018). Teori-teori manajemen sumber daya manusia. Prenada Media.

3. Fahmi, Irham. (2012). Manajemen teori, kasus, dan solusi. Bandung: Alfabeta.

4. Kasmir. (2018). Manajemen Sumber Daya Manusia Teori dan Praktik (Cetakan Ke). Jakarta: Penerbit PT. Raja Grafindo Persada.

5. Sedarmayanti. (2017). Manajemen Sumber Daya Manusia.

6. Silalahi, Ulber, \& Mifka, Sabda Ali. (2015). Asas-asas manajemen. Refika Aditama.

7. Soetrisno, Edy. (2016). Manajemen sumber daya manusia. Kencana.

8. Sudarmanto. (2014). Kinerja dan Pengembangan Kompetensi SDM. Yogyakarta: Pustaka Pelajar.

9. Sulistiyani, Ambar Teguh dan Rosidah. (2018). Manajemen Sumber Daya Manusia Pendekatan Teoretik dan Praktik Untuk Organisasi Publik. Yogyakarta: Gava Media.

10. Suwatno, H., \& Priansa, Donni Juni. (2011). Manajemen SDM dalam organisasi Publik dan Bisnis. Bandung: Alfabeta.

11. Wibowo. (2016). Manajemen Kinerja (Cetakan Ke). Jakarta: PT Raja Grafindo Persada.

12. Yuniarsih, Tjutju dan Suwatno. (2016). Manajemen Sumber Daya Manusia Teori Aplikasi dan Isu Penelitian. Bandung: Penerbit Alfabeta. 
